\title{
ANARCHISM AND THE PROBLEM OF ORDER*
}

Beth Hartung

University of Nebraska-Lincoln

Mid-American Review of Sociology, 1983, Vol. VIII, No. 1:83-101

\section{INTRODUCTION}

If the gentlemen in power were really so intelligent and so devoted to the public cause ... what a pretty government and paternal utopia we should be able to construct!

-Peter Kropotkin

We do have to go back some time in history ... to find examples of societies without the state, that being the particular burden of the contemporary world. And yet when we do, ... we almost never fail to find an extraordinary record of stability and equilibrium that suggests...that the human animal without the patterns of state and the pillars of authority, tends to peace not war, to self-regulation not chaos, to cooperation not dissension ... to order not disarray.

-Kirkpatrick Sale

To suggest that the State in modern industrial societies is less than benignly neutral is hardly startling. But to suggest that the State and other forms of imposed authority be replaced by a decentralized system of community-based cooperatives, as do contemporary anarchists, undermines the dominant mode of political organization and the number of vested interests within it. A socio-political theory which purports to be a scheme for social transformation invites charges of idealism and naivete. Lay criticisms usually elaborate such points as international interdependency, the imperatives of defense, nuclear energy, public services beyond the competence of community and

*A version of this paper was presented at the 1982 annual meeting of the Midwest Sociological Society, Des Moines, Iowa. 
individual, and other grave concerns (Sale, 1980:467). These are large problems, born of industrial society and attributable in part to it. The intent of this essay, rather than addressing these global problems, is much more modest.

Within sociology, critiques of anarchism are more likely to be theoretical, centered specifically on (1) the notion that social order cannot exist without inevitable structural inequities (i.e., hierarchical organization); and generically upon (2) the idea that the "scientific" constructions of modern sociology do not lend themselves to the study of the local and the particular. This second dilemma is at the heart of wedding political practice to social theory. Certainly, the "problem of order" is an important and unresolved one. As concerns anarchism, the popular image still corresponds to a "state" of anarchy as the equivalent of chaos.

On the contrary, the community of communes (from Buber) that is the good society of various libertarian schemes presumes social order based on cooperation. The following discussion presents an examination of the theoretical tenet of anarchism that social order can, indeed, be based upon free cooperation vis-a-vis sociological conceptions of order. The argument may be presented in three parts. Providing a framework for "new forms of human relationships" requires a systematic effort on the part of anarchist scholars. First, anarchism as critique must show how the reified notion of State has undermined community life and cooperation; and further, to show through scholarship and example, that without the State, order will not dissolve into chaos. Thus, instances of anarchistic social order must complete the argument. Accusations of idealism can only be countered with historical examples; criticisms concerning a lack of rigor with theoretical synthesis.

\section{A Note Concerning Sociology and Order}

Within the discipline of sociology, a theory is likely to be dismissed as unsound if construed as ideological (see Martindale's [1960] treatment of conflict theory departing from Marx). Ideology, in our discipline, is nothing if not perjorative. By an interesting turn, however, sociological theorists have relied heavily upon political schemes and philosophies for a resolution of the problem of order. Order rests either upon coercion(conflict theories), consensus (structural-functional theories) or upon striking a balance between collective and individual advantages (exchange theories or some such bifurcation) (Mennell, 1974: 117).

Supposing the notion of order could be exempt, for the moment, from the question of ideological bias, the bases of order from each perspective beg the question of the scholar's own values. Consensus, and what constitutes consensus, is hardly value-free. Neither are the ideas of coercion or the "distributive justice" precept underlying exchange theory. If such values can be explicitly identified within the accepted body of sociological theory, criticisms of anarchism as apolitical or antipolitical ideology ring hollow. This point bears elaboration.

Both the structural-functional model and the economic exchange model assume a social structure based on merit that is essentially just. Within the meritocracy, various inequities are not necessary "evils" but inevitable necessities. Specific theories based on these models, such as Davis and Moore's functional theory of stratification and Homan's human exchange theory, offer barely concealed rationales for the continuation of thingsas-they-are in an exercise of politicalization by omission.

Davis and Moore (1945) begin their controversial treatise with the statement that no society is classless. They propose to outline universal (ahistorical and transcultural) features of stratification as a functional mechanism for insuring that the best qualified reach the best position. Maintenance of the social order, in their view, is an equitable process, and social inequality is important to that social order. "Social inequality is... an unconsciously evolved device by which societies insure that the most important positions are conscientiously filled by the most qualified persons" (emphasis mine) (Davis and Moore, 1945: 243). Inequality is necessary, according to this view, due to (1) dispersion of talent through a population; and (2) scarcity in this pool of talent. Even though this pool of talent is limited, qualified individuals must still be induced to strive for a higher position by reaping greater economic rewards, prestige, and consumer access to cultural diversions. These rewards become 


\section{Mid-American Review of Sociology}

socially expected, and are therefore built into the demanding position. Positions are imbued with functional importance, then, on the basis of "greatest social good" and the time and talent involved in training. By their use of the word "sacrifice," Davis and Moore highlight the altruism and inherent justness of their scheme. Great industrial social orders continue to be stratified not only due to the necessity of maintaining an increasingly specialized society, but because the scheme is just: those who invest more, get more.

In exchange theory, the competition of the marketplace, and the notion of profit maximization, lie at the base of human relations according to Homans (1961). Although Homans does not deal directly with the issue of social order, his rules of elementary social behavior are those upon which order is based. Of the five formal propositions offered by Homans, the first four come directly from operant pyschology (Hingers and Willer, 1979; Miley, 1981). ${ }^{1}$ The final proposition has to do with the law of distributive justice, or justice in the rewards and costs between persons.

A man in an exchange relation with another will expect that the rewards of each man be proportional to his costs-the greater rewards, the greaters the costs-and that the net rewards, or profits, of each man be proportional to his investments-the greater the investments, the greater the profit (Homans, 1961: 75).

\section{It follows that,}

the more to a man's disadvantage the rule of distributive justice fails of realization, the more likely he is to display the emotional behavior we call anger (1961:75).

Social order, then, is based upon reciprocity, or as Miley (1981) has argued, "false reciprocity." That is, in the first part of Homan's definition of distributive justice, rewards are "proportional" to costs; in the second part, the notion of profit and investment are introduced converting "a statement of the

\section{Anarchism and the Problem of Order}

reciprocity norm into a statement about rational profit maximaximixing" (Miley, 1981:9). According to Homan's scheme, we are all narrowly economic men and women. In the marketplace of social life, caveat emptor applies to all human relationships.

In these "scientific" schemes, social order is contingent upon either the distribution of goods and services based on a paucity of talented and trained individuals hierarchically channeled; or upon a tacit social contract between "buyer" and "seller." The difference between these particular sociological theories and anarchism is vast in many respects. But again, the point to be made here is that all theory, in making assumptions about the nature of human beings, is political. Mainstream sociology attempts to treat social-structural abstractions (like order and equality) as if theory was divorced from political assumptions about the character of reality. Theories geared to the maintenance and justification of the status quo somehow have become anesthetized from social responsibility. Rarely, if ever, is an attempt made to link theory and practice in an effort to bring about a scheme for social transformation. Indeed, theory and practice become translated as the "practice of theory," a rather sterile pursuit.

By contrast, anarchism in its various forms-individualist anarchism, anarchosyndicalism, anarchocommunism, pacifist anarchism (Woodcock, 1969)-offers a critique of existing social structures, a scheme for social transformation, and finally, a surprisingly consistent vision of the "good society,"2 surprising because of the great diversity of revolutionary strategies and economic organizations proposed within various schools of anarchism. As a socio-political theory, it has been subject to a great deal of perjorative analysis and gross misunderstanding; as a pragmatic scheme, it has been made impotent by being subsumed under an ideological umbrella of "radical" (Bookchin, 1978).

The history of anarchism as a movement is admittedly uneven. Until quite recently anarchism as a body of acts and attitudes had dwindled to practical insignificance. Now in the process of re-emerging on the historical stage, it encompasses 


\section{Mid-American Review of Sociology}

a number of movements closely identified with the counterculture of the sixties and heretofore seen as separate trends: the imperatives of radical ecology (Bookchin, 1979:177); the cooperation of various intentional communities (Clark, 1981); the organismic worldview of radical feminism (Kornegger, 1975). ${ }^{3}$ Anarchism for a time, to borrow a phrase, had retreated to the sphere of the imagination although "it is no doubt better to have imagination without a movement than a movement without imagination" (Clark, 1981:20). The basic formulations from the classical period of anarchism provide the bases of the contemporary anarchist synthesis. Anarchist social theory questions whether a large-scale, centralized, mechanized system can be the means to a more humane society. Its goals can be stated simply: disappearance of the state, disappearance of class rule, attainment of human equality and social management of the economy (Clark, 1980:84-86). At the base of anarchism is the ideal of communal individuality; restated, human beings are social creatures whose distinctive personalities (individualities) can best be nurtured in a strong community.

Social Order and Free Cooperation

Anarchist scholarship is contingent upon finding a necessary balance between abstraction (generalizations) and the concrete (the "local and particular" mentioned earlier). Once a theory is taken from the streets or factories and into the academy, there is the risk that revolutionary potential will be subverted to scholarship (Bookchin, 1978:5); in other words, knowledge becomes technology.

(G)eneralizations, valuable as they may be, are all too often achieved by defining social life in highly formalized and abstract terms. The 'laws' and categories derived by creating formal typologies are often gained at the expense of insights that the molecular structures provide and the challenging conclusions they imply (Bookchin, 1978:16).

But there is no denying that the libertarian problematic has survived as the result of scholarship and reissuing works by
Anarchism and the Problem of Order

Proudhon, Bakunin, Kropotkin and others. Contemporary anarchist theory and practice departs from the premises of the classical period, restating (rather than reformulating) the basic precepts mentioned above.

Anarchism generically begins with the assumption that patterns of domination-including classism, racism, sexism and heterosexism-can be traced to the hierarchical imposition of authority. The disappearance of the state and of class rule fosters a commitment to radical egalitarianism. This raises the central question of this analysis: Anarchy literally means no government. Without government, there is the implication of a lack of order, of chaos. If human sociability and cooperation are suppressed by the State ["if we want to strengthen society we must weaken the State" (Ward, 1973:20)], what then is to be the basis for social order?

There are two answers to this question. The anarchist theory of spontaneous order is situational and can be amply illustrated without looking much further than current events. The second, order based upon voluntary (free) cooperation is more complex and departs from a formal theoretical critique of the State. Taking the former first, the theory of spontaneous order states that "given a common need, a collection of people will ... by improvisation and experiment, evolve order out of the situation-this order being more durable and more closely related to their needs than any kind of order external authority could provide" (Ward, 1973:28). As Kropotkin wrote in The Conquest of Bread,

Give the people a free hand, and in ten days the food service will be conducted with admiral regularity.... Speak of the organizing genius of the 'Great Misunderstood,' the people, to those who have seen it in Paris in the days of the barricades, or in London during the great dockers' strike, when half a million of starving folk had to be fed, and they will tell you how superior it is to the official ineptness of Bumbledom. ... In any case, a system which springs up spontaneously, under stress of immediate need, will be infinitely preferable to anything invented between four walls by hide-bound theorists (1972b:91). 
It is under stress "of immediate need" that the theory of spontaneous order may be observed-in times of revolution, natural disaster and "mass" events. When technology fails (as in the complete blackout of New York City a few years ago) and the rules of conduct are suspended; when thousands of people came together for the Woodstock Music Festival over a decade ago and peacefully coexisted; the theory of spontaneous order underlaid action taken. In such situations, individuals become living presences in the execution of social policy and action. These examples, while not isolated or difficult to summon, are characterized by their brevity. Traditional structure (form) is absent or in disarray and social order takes on a different content. The order experienced and created by the participants is situated in a fleeting social anti-structure.

Sustaining spontaneous social order based upon voluntary cooperation requires a more lengthy recapitulation. Here, classical anarchists were fond of bringing to bear anthropological evidence featuring stateless, preliterate tribes and in the zeal to convince, mistaking the "tyranny of custom" for the spirit of cooperation. For example, Kropotkin's search for an unarticulated anarchism of the people led to over-generalizations about "tribal solidarity" in "Mutual Aid Among Savages" (1902). Archaic and historical evidence, while useful, leads back to that argument that anarchism can only work in small, preindustrialized, "primitive" groups. The statement belies an understanding of the complexity of any human group, in any context, and of anarchism irself. Indeed, anarchy is a function of a society's complexity and multiplicity of social organizations (Ward, 1973:50). Kropotkin's Mutual Aid, while not exempt from the charge of revisionist history and some misinterpretation, was an early attempt to devise a typology of forms of social order based on cooperation and emphasizing unity in diversity.

Briefly, according to Kropotkin's universal scheme, the tribe or clan gave way to the village community, later replaced by the medieval free city. He saw the free city, in its later form, as an autonomous, decentralized State bearing little resemblance to the modern State (Sale, 1980:462). These early social forms, culminating in the diversity of the free city represented the possibility of a return to cooperative forms of social organization.

Among early peoples, cooperation was based along blood lines. When bonds of common descent were loosened, a new form of cooperative life based on commonly-held land, the "barbarian village," replaced the clan as the dominant form of social organization (Kropotkin, 1972:170-175). In the 10th and 11th centuries, Europe was invaded by various warrior bands. Kropotkin wrote that as town walls fortified villagers from outside attack, so also did they symbolize inner fortification against the rule of thousands of petty feudal lords. At this time, the medieval city appears.

The medieval city was an attempt at organizing, on a much grander scale than in a village community, a close union for mutual aid and support, for consumption and production, and for social life altogether, without imposing upon men the fetters of the State, but giving full liberty of expression to the creative genius of each separate group of individuals in art, crafts, science, commerce and political organization (Kropotkin, 1972:188).

The final point of Kropotkin's historical analysis is that the State, as comprised of dominant minorities and subordinant majorities, is "but one of the forms of social life" (1972:132) and certainly not the "highest" form. It was his contention that the State was built on the annihilation of free union. This last point leads logically to a more formal anarchist critique regarding cooperation, order, and the State extrapolated from Kropotkin. As mentioned earlier, it is necessary to first show that the State has undermined cooperative life before presenting any proofs regarding social order based on cooperation.

The Anarchist as Critic: Society vs. the State

The assumptions of anarchist theory regarding cooperation vis-a-vis the State can be ordered as follows:

1. Voluntary cooperation is engendered within the community. 
Community can be defined in territorial and cultural terms, both material and ideational, where people are united by common values, interests, ideas, myths, rituals, symbols and artifacts. It is further a matter of degreethe extent to which people share interests, values and objects of cultural/emotional attachment.

Union, or solidarity, comes about by virture of emotional attachment to the community and by adherence to certain internalized rules.

Cooperation can be defined as the interdependence between altruism (welfare of the community) and individual needs and wants.

2. The community is responsible for the provision of public goods.

Public goods are those "good(s) which (have) the property that, if any amount of the good is provided, any member of the public in question can benefit from it whether or not he contributed to its provision" (Taylor, 1976:3).

3. The provision of public goods is dependent upon size: the larger the community, the less likely is voluntary cooperation in the provision of goods.

The smaller the community, the greater the ease of facilitating public sanctions and censures resolved by the community as opposed to institutional censure imposed by outside authority (police, military, codified norms of laws, etc.).

4. The intervention of the State in small communities, providing a framework for rapid growth and assimilating or destroying smaller communities, exacerbates the conditions claimed to justify its existence (i.e., people will not voluntarily cooperate; problems of security for persons and property).
5. By virtue of assimilation, the State thus undermines the requisites of Community as a territorial and affective state, upon which cooperation is based.

This scheme is a lengthy recapitulation of Kropotkin's simple statement quoted above. From here anarchist theory and practice departs. If the basis of the theory is order from cooperation, the theory is predicated upon the destructive role of the State. It becomes clear that anarchist theory and anarchist order presuppose a certain kind of society. Beginning with the first point, community as a cultural and territorial union cemented by the solidarity of values, myth, ritual, and so forth, necessitates examination of the "good" society and social order within it.

Libertarian practice has historically taken two forms: those who have conceived of the problem in terms of an initial class struggle, and those with a multi-dimensional, cultural orientation (Clark, 1981:23). In the United States, the former can be traced to nineteenth century immigrant movements and the revolutionary syndicalism of the IWW. These movements, which pinpointed capitalism and the State as the roots of domination, were based largely on anarchosyndicalism and revolutionary syndicalism. In this type of anarchism the workers are organized to overthrow the State through insurrection or economic class action (Clark, 1981:23)

The second form, with which anarchocommunism is most closely associated and which will be examined here, has been implemented in various intentional communities (Kropotkin's agro-industrial communes). From the nineteenth century to the present, communitarian living arrangements have provided examples of the attempt to move towards voluntary cooperation, direct social participation, decentralization and egalitarianism. From the myriad of communal groups that flourished during the nineteenth centruy (see Noyes, 1966; Nordhoff, 1965), to the countercultural communes of the sixties, to the present "back to the land" move toward voluntary simplicity, the "libertarian problematic" has been expressed in direct action (Clark, 1981). ${ }^{4}$ 
There is a rich literature and tradition of intentional communities of the past two centuries in the United States. In the encyclopedic listings of historical communities (for e.g., Fogarty, 1980) the sheer number of communities that flourished for a short time and then floundered are staggering. Moreover, in the nineteenth century as in the twentieth, anarchist thought percolates through the lifespan of a community but only a few cooperatives identified themselves as such (notably Home, Washington, and the Ferrer Colony at Stelton, New Jersey). Many of the nineteenth century efforts which blended utopian socialism with anarchistic elements were doomed to failure. And some more recent anarchist groups have interpreted anarchist theory as a series of slogans. In failing to provide alternative institutional and organizational forms, these communities were also doomed. Taking as an example the Ferrer Colony, the concept of community in the anarchist sense can be examined less abstractly:

1. "Voluntary cooperation is engendered within the community."

The Ferrer Colony and Modern School, an alternative community and institution, lasted nearly four decades and cannot, of course, be chronicled in great detail here. Very briefly, the Ferrer Modern School and Association was established in New York City October 13, 1911 (Veysey, 1973:81). As a result of political upheavals and discord within the association itself, the decision was made to build a rural community around the school. The school as a libertarian institution acted as a cohesive force, uniting a diverse group of individuals. A farm was purchased in 1914 at Stelton, New Jersey. The Ferrer organization purchased 143 acres at $\$ 100$ per acre. Individual plots were resold to colonists at $\$ 150$ an acre in lots of one to two acres each (1973:116). There was no formal governance; colonists were free to come and go and visitors were encouraged. In the first years of hardship, a mood of solidarity was reported by an anonymous colonist,
We have no greedy employers, no submissive workers, no wages, no hours,-we have artists expressing themselves joyfully .... Members here do not discuss questions of solidarity, brotherhood and mutual aid-they go right ahead and practice them (quoted in Veysey, 1973:119).

2. "The community is responsible for the provision of public goods."

At Ferrer, the colonists either commuted to jobs in nearby New York or attempted to raise poultry and vegetables on their individual garden plots. The colony was never completely selfsustaining, but for fifteen years, a local cooperative helped colonists satisfy their needs at fair prices (Veysey, 1973:129). Despite an inability to be completely self-sufficient, the community was economically viable.

3. "The provision of public goods is dependent upon size."

Within six or seven years, The Ferrer Colony was a success. From 1916 to the middle 1920s, the school and colony grew continuously. "By September, 1918, fifty-one dwellings existed in the colony, and about twenty families lived there year-around. The summer population was then estimated at 200" (Veysey, 1973:121). At its peak, Stelton contained about one hundred families in the winter months and twice as many in the summer. "By 1922, some eighty or ninety houses had been built in the colony; this was to be about the peak number" (Veysey, 1973:121). At its peak, Stelton contained about one hundred families in the winter months and twice as many in the summer. "By 1922, some eighty or ninety houses had been built in the colony; this was to be about the peak number" (Veysey, 1973: 122).

The Ferrer community was not immune to internal disputes and factions which seemed to intensify during the late 1920s. However, its final demise as a community took place during the second World War when the U.S. Army built barracks on the property adjacent to that owned by Stelton residents. 


\section{Mid-American Review of Sociology}

With the building of Camp Kilmer in 1941, the proximity to several thousand soldiers "produced an atmosphere of theft, vandalism, and ...rape" (Veysey, 1973:172). Many older residents sold their homes and moved. The community failed to reproduce itself and entered a period of decline. It is, however, ironic that what may have been an inevitable demise was hastened by external (statist) intervention.

\section{Social Anti-Structure and Anarchistic Social Order}

This brief sketch of the Ferrer Colony illustrates what Bookchin has called the reconstruction of revolutionary theory and practice. As a community, it represented a "movement towards cell-tissue society in a physical sense" and an attempt to abolish domination and hierarchy in all forms (1978:20). To move towards cell-tissue society is to put principles into action, as did the Ferrer colonists. In the context of the anarchist collective, the objective is not to recruit (add) members but to reproduce (multiply) the collective. As mentioned, Ferrer failed to reproduce itself, but for several decades it maintained an optimum size with a diverse population. There was no need to recruit members or students for the school, and an open door policy meant colonists could sell their land and leave the community fully reimbursed. The population was constantly changing.

Although there was leadership at Ferrer, it represented an attempt to abolish domination and hierarchy in all forms. Community meetings were held on a regular basis. By all reports, they were quite lively and even heated at times. This kind of direct democracy is, of course, contingent on size. The anarchist collective, because of the commitment to egalitarianism is of necessity small. "The size of a collective is essentially a limitation of its authority" (the anti-mass, 1979:343-344). Within the small community, emerging inequalities can be immediately dealt with and more readily identified. The anarchist's reliance on the individual gives each man and woman choice and ultimately, responsibility for maintenance of an equitable, cooperative system. Indeed, as Bookchin writes,
Anarchism and the Problem of Order

there is no way to immunize any social formation, even the most dedicated anarchist groups, from hierarchical relations except through the wisdom of 'self-consciousness' that comes from the 'self-actualization' of the individual's potential for self-hood (Bookchin, 1979:9).

(This is Bookchin's rather pedantic way of saying that we all have our shortcomings.) The abrogation of responsibility for social maintenance to individuals may prove to be a heavy burden, and raises a third point.

In the intentional community, with group production and consumption entered freely by its members, each member has an equal voice. Each member must also assume responsibility for work to be done, which was not a problem at Ferrer as long as it was a community (in the affective sense). Buildings were erected, gardens were planted, leaving time for the enjoyable pursuits of swimming, lectures and other community-produced entertainments. Still, Ferrer is no longer in existence. With few notable exceptions, the intentional community appears to be relatively short-lived. Why?

It is essential to this analysis to examine a key problem with anarchistic social order in practice, perhaps all too obvious to the reader by now. Anarchistic social order, based on voluntary cooperation (with the emphasis on "voluntary"), assumes non-coercive reciprocity in human relationships. It assumes, further, a reciprocity based upon human bonds; a reciprocity that defies externally imposed social structure. Let me return to a point made earlier-that the order arising "under stress of immediate need" is situated in a fleeting social anti-structure. This condition has been described by the anthropologist Victor Turner as "communitas." Communitas is an immediate, genuine human bond; "the bonds of communitas are undifferentiated, egalitarian, direct, extant, nonrational, existential" (Turner and Turner, 1978:250). Characterized by spontaneity, breaking in "through the interstices of structure... and from beneath structure" (Turner, 1969:127), attempts to sustain order based on anti-structure (communitas) are frequently disappointing. 
In such moments of experienced communitas, "self has the mystical experience of unity with others in an egalitarian sense; the self becomes more collectively human" (O'Donnell and Hartung, 1982:13). So enters the mystical element with anarchism, difficult to reconcile with the more rational theoretical propositions outlined earlier. Difficult, but not impossible. One needs to ask oneself whether the rational and mystical are, indeed, dichotomous states or if this is not another obstacle thrown up by "hide-bound theorists" as defying empirical reality.

\section{CONCLUSIONS}

In summary, anarchistic social order, arising spontaneously to meet each unique situation and based upon cooperation, does not correspond to the sociological conceptions of order based on consensus, coercion, or distributive "justice." The anarchist is suspicious of artificial consensus imposed by external regulating agencies. Society, defined by human sociality, is not homogenous but comprised of diverse individuals. And while the anarchist does not deny the coercion implicit in this codified social order, anarchists are deeply suspicious of any revolutionary government as well. Aside from this, the "revolution" does not appear imminent. As mentioned, the closest corresponding sociological conception of order is the notion of noncoercive reciprocity, stripped of economic overtones and founded on essential human bonds. From this it follows the anarchist assumes that human beings, if not essentially "good," are essentially social. Thus, the importance of community in defining individuality. So much for theoretical abstractions.

What is often neglected in a theoretical scheme is the cultural dimension, so important in translating a theory into practice. Anarchism, as mentioned earlier, is a function of a society's complexity. Both capitalism and socialism in practice, based historically on unlimited growth, have simplified "social life to the level of the inorganic" (Bookchin, 1978:16). As the environment is denuded and social life increasingly fragmented, a response has been forthcoming. There is an unoccupied social domain left untouched by a massive bureaucratic system. This domain is being filled by cooperatives, neighborhood associations and various other groups created in response to social ills (Bookchin, 1979:28). This incipient movement, congenial to the American tradition, has a great radicalizing potential; potential that may never by actualized on a "mass" scale but valuable for this very reason. Anarchism operates rather like communitas, slipping in and out of the interstices of social groups and social structure. Anarchism as theory offers a viable critique of the homogenizing, destructive role of hegemony in all its forms. And anarchism as practice is remarkably prolific and adaptable.

\section{FOOTNOTES}

1. That Homans does not really separate animal from human behavior has endeared him to evolutionary or social biologists. Not surprisingly, maximizing one's own gain is very much akin to "maximizing reproductive fitness"' (see Alexander, 1979).

2. Several scholars, notably historians Woodcock (1969) and Joll (1964), have commented on the uneasy fit of "rational" anarchist theory with the ascetic, almost mystical tendencies of many of its proponents. Indicative of this is the appellation given Kropotkin during his lifetime, that of the movement's "secular saint."

3. One would be remiss in neglecting to mention that the re-emergence of anarchist theory encompasses not only movements identified with the Left, but Libertarianism as well. It is arguable, however, whether libertarian practice corresponds to the Libertarian "platform" of the $1980 \mathrm{~s}$; or whether the communal individuality of anarchism corresponds to uninformed individualism.

4. These two forms have been expressed in somewhat different terms by Ritter (1980:151). In the first instance, some particularly significant social activity is rearranged leaving other structures undisturbed (i.e., education, worker self-management). In the second, all activities are transformed in a circumscribed place, usually rural, in some kind of community setting. Ritter argues, and I would agree, that many intentional communities in the sixties were implicitly anarchistic. A few, such as Morningstar Ranch in California, explicitly acknowledged of understood their anarchist heritage. 


\section{REFERENCES}

Alexander, R.

1979 Darwinism and Human Affairs. Seattle: University of Washington Press.

the anti- "Anti-mass-methods of organization for collectives" in Erlich mass et al. (eds.) Reinventing Anarchy. London: Routledge and 1979 Kegan Paul

Bookchin, $M$.

1978 "Beyond Neo-Marxism," Telos (36), 5-28.

1979 "Self-Management and the New Technology," Telos (41), 5-16.

Clark, J.

1980 "Marx, Bakunin and the Problem of Social Transformation," Telos (42), 80-97.

1981 "The Politics of Liberation: From Class to Culture," Black Rose (7), 20-35.

Davis, K. and Moore, W.

1945 "Some Principles of Stratification," American Sociological Review (10), 242-249.

Fogarty, R.S.

1980 Dictionary of American Communal and Utopian History. Westport, Connecticut: Greenwood Press.

Hingers, R. and Willer, D.

1979 "Prevailing Postulates of Social Exchange Theory," in Scott McNall (ed.) Theoretical Perspectives in Sociology. New York: St. Martin's Press.

Homans, G.C

1961 Social Behavior: Its Elementary Forms. New York: Harcourt, Brace and World, Inc.

Joll, J.

1964 The Anarchists. Boston: Little, Brown and Company.

Kornegger, $\mathrm{P}$.

1975 "Anarchism: The Feminist Connection," The Second Wave Kropotkin, $\mathrm{P}$. (spring), 26-37.

n.d. "Anarchist Communism: Its Basis and Principles." London: Freedom Press, pamphlet.

1899 Memoirs of a Revolutionist. Boston: Houghton Mifflin.

1902 Mutual Aid: A Factor of Evolution. Boston: Extending Horizons books.

1968 "Anarchism: Its Philosophy and Ideal," in Kropotkin's Revolutionary Pamphlets. New York: Benjamin Blom. orig. pub. 1927.

1972 "Excerpts from Mutual Aid," in Capouya and Tompkins (eds.) The Essential Kropotkin. New York: Liveright Press.
Kropotkin, $\mathrm{P}$.

1972b The Conquest of Bread. New York: New York University Press.

Martindale, D.

1960 The Nature and Types of Sociological Theory. Boston: Houghton Mifflin.

Melville, $\mathrm{K}$.

1972 Communes in the Counterculture. New York: William Morrow and Co.

Mennell, S.

1974 Sociological Theory: Uses and Unities. New York: Praeger Publishers.

Miley, J.D.

1981 "False Reciprocity and the Theory of Exchange." Unpublished manuscript.

Nordhoff, C.

1965 The Communistic Societies of the United States. New York: Shocken Books. Orig. ed. 1875.

Noyes, J.H.

1966 History of American Socialisms. New York: Dover Books. Orig. ed. 1870

O'Donnell, D. and B. Hartung

1982 "Rites of Passage in an Adolescent Subculture: Some Thoughts on a Haunted House." Unpublished manuscript.

Ritter, A.

1980 Anarchism: A Theoretical Analysis. Cambridge: Cambridge University Press.

Sale, $\mathrm{K}$.

1980 Human Scale. Boston: Houghton Mifflin.

Taylor, M.

1976 Anarchy and Cooperation. London: John Wiley and Sons.

Turner, V.

1969 The Ritual Process. Chicago: Aldine.

Turner, V. and E. Turner

1978 Image and the Pilgrimage in Christian Culture. Oxford: Basil Blackwell.

Vesey, L.

1973 The Communal Experience. New York: Harper and Row.

Ward, C.

1973 Anarchy in Action. London: George Allen and Unwin Ltd.

Woodcock, G.

1969 Anarchism: A History of Libertarian Ideas and Movements. New York: Meridian Books. 2nd ed. 